\title{
THE MAIN PESTS MICROBIOLOGICAL CONTROL IN VEGETABLE, BACCATE CROPS AND POTATO IN LENINGRAD PROVINCE
}

\section{S.A. DOBROKHOTOV ${ }^{1}$, A.I. ANISIMOV ${ }^{1}$, S.D. GRISHECHKINA ${ }^{2}$, L.G. DANILOV ${ }^{3}$, G.R. LEDNEV ${ }^{3}$, K.N. FURSOV ${ }^{1}$}

\author{
${ }^{1}$ Saint Petersburg State Agrarian University, 2, Peterburgskoe sh., St. Petersburg, 196601 Russia, e-mail anisi- \\ mov_anatoly@mail.ru; \\ ${ }^{2}$ All-Russian Research Institute for Agricultural Microbiology, Federal Agency of Scientific Organizations, 3, sh. \\ Podbel'skogo, St. Petersburg, 196608 Russia; \\ ${ }^{3}$ All-Russian Research Institute of Plant Protection, Federal Agency of Scientific Organizations, 3, sh. Pod- \\ bel'skogo, St. Petersburg, 196608 Russia \\ Received May 8, 2015
}

\section{Abstract}

The using of microbiological preparations for plant protection steadily extends in the world. A short list of microbiological preparations that are authorized for applying on the territory of the Russian Federation for insect pest control on crops is presented in the State Catalog of pesticides and agrochemicals. However, the biological preparations allowed for berry crops is very limited in number, and for pine strawberry no one is indicated in the Russian Federation State Catalog. In the represented work the capability of microbiological and other ecologically friendly preparations to control main pests on vegetable (cabbage, carrot, swede), baccate (blackberry, red raspberry, strawberry) crops and potato are considered under the conditions of Leningrad Province. Experiments were carried out in 2005-2014. In the research, we specified norms, terms, frequency, and rate of treatment with microbiological preparations. The tested preparations are created on the basis of different Bacillus thuringiensis Berliner strains (Bitocsibacillin, Lepidocid, Batsikol), entomopathogenic eelworm Steinernema carpocapsae Weiser (Nemabakt), also the laboratory sample based on entomopathogenic fungi Metarhizium anisoplia Metchn. was used. Some agrotechnical methods for insect pests control were investigated too. We studied the effect of various terms of planting, field isolation and distribution of the insect pests on the large territories, and the number on insect pests as influenced by nutrient input during plant growth. In each experiment there was a control variant (without application of any preparations). A chemical or biochemical preparation allowed for use in the territory of the Russian Federation was mostly used as a standard for comparison. The biological efficiency (BE) of the investigated preparations was estimated. It was found out that rather often the microbiological preparations were inferior to the chemical standards by BE. However, Bitocsibacillin and Lepidocid developed and manufactured in the Russian Federation can provide the 90-95\% BE against the cabbage white butterfly. The BE of these preparations against cabbage moth ranged from $60 \%$ to $80 \%$. The biological efficiency of Batsicol against cruciferous tiddlywinks was 60-80\% when double treatments were used. The BE reached $100 \%$ in control of Colorado beetle larvae with Bitocsibacillin and Batsikol. BE of both Nemabakt and laboratory sample of $M$. anisoplia in wireworms control varied at 60-80\% levels. On pine strawberry against strawberry blossom weevil the highest BE, comparable with efficiency of Fytoverm preparation, was observed for Batsikol. It was shown that a combination of bioinsecticides and biofungicides can be helpful in pine strawberry pests control. Thus, together with some repellents and agrotechnical methods the biological preparations can provide reliable protection of vegetable and berry crops, and potato against the main insect pests, at least in the conditions of the Leningrad Province.

Keywords: Leningrad Province, vegetable and baccate crops, potato, insect pests, microbiological preparations, agrotechnical methods, biological efficiency.

The use of microbiological preparations for plant protection from pests is constantly expanding in the world practice. According to experts, the share of biopesticides on the market will reach $20 \%$ in 2020 amounting to $\$ 8$ billion [1]. The scale of the use of the Bacillus thuringiensis Berliner (Bt)-based products ranks first in the world. In 2009, they were used in the area of 50 million ha, and the proportion of the United States was 33 million ha (2). These agents are 
effective against the pests that belong to various classes, including phytopathogenic nematodes [3]. The low toxicity to target objects and persistence of bacteria in the environment, as well as the possibility of including bacterial genes responsible for the synthesis of toxic metabolite proteins in the plant genome, contribute to the promotion of transgenic crops in agriculture [4, 5].

Entomopathogenic products based on the fungi Metarhizium anisopliae Metchn. and Beauveria bassiana Balsamo are important in the click beetle larvae control $[6,7]$. Although the biological effectiveness (BE) of the samples with only $B$. bassiana was low in field trials [8], when used together with the biochemical agent created on the basis of soil actinomycete Saccharopolyspora spinosa, an increase in BE was achieved [9]. An area associated with entomopathogenic nematodes (EPN) is developing rapidly. Five commercial companies in the United States and five in European countries produce EPN-based products that are effective against a wide range of pests [10].

In Leningrad Province, agricultural joint-stock companies mainly use chemical plant protection products (PPP) [11]. The microbiological method is used in limited areas due to the higher cost of biologics, lesser biological efficacy compared to the chemical method, and the difficulty of complex plant biological protection. A short list of microbiological preparations that are authorized for the use in the territory of the Russian Federation for pest control is presented in the State Catalog of pesticides and agrochemicals. In 2014, the biological method amounted to only $1.9 \%$ of the total pest control events [12].

The search for effective microbial plant protection products is one of the main directions [13-15]. The emergence of new biopreparations based on B. thuringiensis (Batsikol) and entomopathogenic nematodes (Nemabakt, Entonem-F) made it possible to develop integrated biological protection of cabbage from cruciferous flea beetles (genus Phyllotreta), cabbage fly (Delia brassicae Bouche and Delia floralis Fallen ), diamondback moth (Plutella xylostella L.), latge (Pieris brassicae L.) and small (Pieris rapae L.) whites, back in 2001. However, the profitability of biological control was low (52\%) due to the cost of Nemabakt used against cabbage fly [16). In 2005, high biological efficacy of Nemabakt against cabbage flies was found when the seedlings were sprayed in trays prior to planting in open ground [17]. The possibility of combined treatment with bio-fungicides and bio-insecticides was also demonstrated [18].

Further scientific research was aimed at increasing the number of products (repellents and biochemical insecticides) against major pests of vegetable crops and potatoes which can be used in organic agriculture [19]. It was necessary to select boipreparations and develop the application of control techniques against click beetle larvae, the wireworms that cause significant harm to potato fields in the North-West of Russia and other countries [20]. Some authors have noted the possibility to use mustard crops to control wireworm as the plants contain glucosinates and isothiocyanates that are toxic to wireworms. At this, the maximum BE was reached with the embedment of $550 \mathrm{cwt} / \mathrm{ha}$ of mustard plant mass into the soil [21].

The greatest losses in berry crops yield, red raspberry and strawberry (80\%), occur at cultivation according to the organic technology [22]. The integrated protection of berry fields in the northern European countries focuses on the use of attracting traps, pyrethroid preparations, the use of entomopathogenic fungi and predatory insects. Bt-based preparations (such as Turex) are used for the strawberry tortrix Acleris comariana Lienig and Zeller control only [23, 24]. To protect plants from strawberry blossom weevil, the products based on azadirachtin of an insecticidal plant (NeemAzal-T/S) and on biochemical preparations of 
Spinosad and Novodor based on B. thuringiensis ssp. tenebrionis are suitable [25]. At this, the preventive chemical treatment against the weevil is noted to be ineffective [26]. Two-time treatment with pyrethroid preparations prior to the opening of $50 \%$ of strawberry buds prevents the increase of blossom damage by blossom weevil [27]. The list of biological preparations allowed for berry crops is very limited in number, and the products for strawberry are not registered in the Russian Federation.

Therefore, it was decided to evaluate the efficacy of microbiological agents in the insect and mite control in strawberries, black currants, and raspberries [2831]. A significant contribution to the development of methods for pest monitoring and control in fruit crops is made by Finnish scientists who investigate damage thresholds. So, for strawberry weevil, the numbers threshold at which pest control is necessary in strawberry is defined as getting 4-5 weevils in a bowl with the shake-off with 100 plants [32].

The purpose of this study was to identify environmentally safe methods and means of protection of vegetable crops, berry fields and potatoes which make it possible to replace chemical PPP, obtain products without residual pesticides, and improve the biocenotic regulation of harmful species abundance. This required to clarify the norms, terms, frequency, and rate of treatment with biological preparations, and to expand the list of biofungicides that can be combined in tank mixtures with bioinsecticides in vegetable crops and strawberry.

Technique. In 2005-2014, at experimental plots of the St. Petersburg State Agrarian University (SPbSAU), All-Russian Research Institute of Agricultural Microbiology (ARRIAM), All-Russian Institute of Plant Protection (VIZR), in horticultural farms and private farms (St. Petersburg and Leningrad Province) the efficacy of microbiological preparations bitoxybacillin (BTB) at 1-3\% concentration, Batsikol (3-5\%), Lepidocide (1\%), experimental sample of the fungus Metarhizium anisopliae-based biological preparation (conidia titer of $2,3 \times 10^{10}$ per $1 \mathrm{~g}$ ), and Nemabakt (application rate of 0.5 million larvae per $1 \mathrm{~m}^{2}$ ) were compared to one another, to the control (no treatment against pests) and to the standard for which a chemical (Arrivo) and biochemical (Fitoverm, Spintor, Vertimek) insecticides were used. BTB and Lepidocide were manufactured by LLC PO Sibbiofarm (Berdsk, Novosibirsk Region), Nemabakt and fungus Metarhizium anisopliae-based biological preparation were produced by VIZR, Fytoverm was manufactures by LLC Farmbiometod (Moscow); experimental sample of Batsikol was produced in ARRIAM. Treatment was performed using the Solo hand sprayer (Solo Kleinmotoren GmbH, Germany) at a rate of working liquid of 400-500 1/ha. The options of experiments (preparations and concentration) are presented in the tables and graphs.

Route surveys (monitoring of pests and entomophages and establishing the timing of the protective measures to start) were carried out in joint-stock agricultural companies of the Leningrad Province (Prinevskoe, Shushary, Detskoselskii, Taitsy). For vegetable crops (cabbage varieties of Kraut Krayzer in 2011, Valentina in 2012, SB-3 and Prestige in 2013 and 2014; carrot variety Berlikum royal; swede variety Novgorod; rape variety Lira), the plot sizes were $10-25 \mathrm{~m}^{2}$. Registration was performed in cabbage, swede, and rape in 25-30 plants (5-6 samples of 5 plants per sample), in carrots in 5-10 plants; to determine the proportion of plants infested 100 plants were studied. All pest phases of insect development (imago, larvae) were taken into account.

The efficacy of biological preparations in potato variety Nevskii was estimated at a garden plot located in the southern region of Gatchina (Leningrad Province). Treatment against Colorado potato beetle (Leptinotarsa decemlineata 
Say) was performed during the hatching of the age I larvae at the end of June (2001). Potato was treated against wireworms with Nematobakt during budding and early flowering, shedding the ridges with an entomopathogenic nematode larvae suspension. Three application techniques were tested for the experimental sample of $M$. anisopliae, i.e. dipping tubers in the suspension of fungus conidia (titer of $4.6 \times 10^{7} / \mathrm{ml}$ of working fluid), wetting of ridge surfaces (conidia titer of $1.7 \times 10^{7} / \mathrm{ml}$ of working fluid) and wetting of bottom grooves (conidia titer of $1.7 \times 107 / \mathrm{ml}$ of working fluid). The number of Colorado potato beetle larvae was estimated on 10 potato plants in each variant, the number of wireworms was registered by soil excavation (sample size of $0.5 \times 0.5 \mathrm{~m}$ and $0.5 \mathrm{~m} \times 1.0 \mathrm{~m}$ at a depth of $0.3 \mathrm{~m}$ ). In some cases (low numbers of wireworms) continuous excavation was performed (area of $1 \mathrm{~m} \times 1 \mathrm{~m}$ ). Potato tuber damage with the larvae of click beetles was estimated in 100 tubers.

Except for the effect of microbial PPP, the effect of autumn embedding mustard plants into the soil on the abundance of wireworms and of the combination of this agrotechnical method with biological preparations ( $M$. anisopliae and nemabakt) was studied in potato. Mustard was seeded in late July, the plants were dug in the soil in the first ten days of September.

Pest control in strawberries was performed in Taitsy farm in industrial crop variety of Tsarskoselskaya; in garden plots located in the vicinity of Pushkin in the varieties of Polka, Surprise for Olympics, Tsarskoselskaya; in the southern part of the Gatchina Region of Leningrad Province in the Zinga-Zanga variety. Red raspberry (Novosti Kuzmina variety) was the study object at the same plot, as black currant was in the Educational and Experimental Garden of SPbSAU (Plotnokistnaya, Vologda, Vigorous and Memory of Alexander Mamkin varieties). Pest abundance in strawberry was estimated at the plots of 4-25 $\mathrm{m}^{2}$; all the plants in the small size plots and 20-25 plants in the large ones were examined. Specifically damaged by strawberry blossom weevil buds and undamaged fruits elements were counted on each plant. The absolute numbers of insects and mites in the sample of 10-30 leaves in any experiment variant were counted in red raspberry and black currant.

In the presence of pests on plants prior to treatment, in both experimental and control variants, the following formula was used (1):

$$
B E=\frac{O_{i} \times K-O \times K_{i}}{O_{i} \times K} \times 100 \%
$$

where $B E$ is biological efficacy, \%; $O_{i}, O$ are pest density at the experimental plot (initial and at the date of registration), ind. $/ \mathrm{m}^{2} ; K_{i}, K$ are pest density at the control plot (initial and at the date of registration), respectively (ind. $/ \mathrm{m}^{2}$, ind./plant). The efficacy of preparations was also calculated based on the reduction of potato tuber damage by wireworm and of strawberry buds by strawberry blossom weevil versus control using the formula (2), since at the time of treatment it was zero at all plots:

$$
E=\frac{K-O}{K} \times 100 \%
$$

where $E$ is reduction of tuber and bud damage, $\% ; O, K$ are tuber and bud damage at the experimental and control plots at the date of registration, $\%$.

Mean values, standard error of the mean or percent were calculated. Significance of inter-variant differences was estimated using the Student $t$-test.

Results. A sufficient efficacy (90-100\%) against large white in Leningrad region was demonstrated by Lepidocide at a concentration of $1 \%$. The biological effectiveness of BTB against diamondback moth was somewhat lower than that of Lepidocide which was inferior to Fytoverm (Table 1). 
1. Biological efficacy (\%) of microbial preparations against the three insect species in vegetable crops depending on the post-treatment period (Leningrad Province, Educational and Experimental Garden of SPbSAU, 2010-2011)

\begin{tabular}{|c|c|c|c|c|c|}
\hline \multirow{2}{*}{ Crop } & \multirow{2}{*}{ Pest } & \multirow{2}{*}{$\begin{array}{l}\text { Preparation, } \\
\text { concentration }\end{array}$} & \multicolumn{3}{|c|}{ Period after treatment } \\
\hline & & & 1 week & 2 weeks & 3 weeks \\
\hline \multirow[t]{7}{*}{ Cabbage } & Diamondback moth & Bitoxybacillin, $1 \%$ & $64.8(1)$ & $75.6(1)$ & $54.3(1)$ \\
\hline & (Plutella xylostella L.) & Lepidocide, $1 \%$ & $67.7(1)$ & $88.4(1)$ & $75.8(1)$ \\
\hline & & Fytoverm, $0.2 \%$ & $71.2(1)$ & $91.8(1)$ & $100(1)$ \\
\hline & Cruciferous flea beetles & Bitoxybacillin, $1 \%$ & $23.4(1)$ & $0(1)$ & $0(1)$ \\
\hline & (genus Phyllotreta) & Bitoxybacillin, $3 \%$ & $52 *-70 *(2)$ & $52 *-68 *(2)$ & - \\
\hline & & Batsikol, $5 \%$ & $39-80 *(2)$ & $69 *-72 *(2)$ & $0(1)$ \\
\hline & & Fytoverm, $0.8 \%$ & $82.3^{*}$ & $72.5^{*}$ & - \\
\hline \multirow[t]{3}{*}{ Swede } & & Batsikol, $5 \%$ & $70.8^{*}(1)$ (registra & ion in 10 days) & $57.7 *(1)$ \\
\hline & & Fytoverm, $0.8 \%$ & $80,4 *(1)$ (registra & ion in 10 days) & $63.8 *(1)$ \\
\hline & & Arrivo, $0.2 \%$ & $100 *(1)$ (registra & on in 10 days) & $88.1 *(1)$ \\
\hline \multirow[t]{3}{*}{ Rape } & & Batsikol, $5 \%$ & $77.6 *(1)$ & $28.4^{*}(1)$ & $66.2 *(1)$ \\
\hline & & Fytoverm, $0.8 \%$ & $85.6 *(1)$ & $40.7^{*}(1)$ & $48.7 *(1)$ \\
\hline & & Arrivo, $0.2 \%$ & $100 *(1)$ & $78.2 *(1)$ & $55.1 *(1)$ \\
\hline \multirow[t]{6}{*}{ Carrot } & Carrot psyllid (Trioza & Bitoxybacillin, $3 \%$ & $27_{2}, 35_{2}, 36_{1} *(3)$ & $33_{2} *-82 *(3)$ & $41_{2} *-56_{2} *(2)$ \\
\hline & apicalis Först.) & Batsikol, $5 \%$ & $16.8_{1}(1)$ & $47.2_{1}^{*}(1)$ & - \\
\hline & & Fytoverm, $0.4 \%$ & $27_{1}-48_{2}(2)$ & $36_{2} *-92_{1} *(2)$ & $0_{2}(1)$ \\
\hline & & Vertimec, $0.4 \%$ & $79.22^{*}$ & $51.8_{2}^{*}$ & $66.8^{*}$ \\
\hline & & Spintor, $0.4 \%$ & $84.42^{*}$ & $60.3_{2}^{*}$ & $41.1_{2}$ \\
\hline & & Arrivo, $0.2 \%$ & $55.7^{*}{ }^{*}$ & $39.0_{2}^{*}$ & $41.1^{*}$ \\
\hline $\begin{array}{l}\mathrm{N} \text { o t e. } \\
\text { brackets } \\
\text { ments a }\end{array}$ & risks denote statisticall & proven values (proba & $\begin{array}{l}\text { differences fr } \\
\text { mark the test } \\
\text { ven for timely }\end{array}$ & $\begin{array}{l}\text { ontrol of mo } \\
\text { formed in cor } \\
\text { rs) or spatially }\end{array}$ & $\begin{array}{l}\text { than } 99 \%) \text {; } \\
\text { parative exper } \\
\text { nuch separate }\end{array}$ \\
\hline
\end{tabular}

BTB demonstrated significant efficacy against crucifer flea beetles in cabbage only with the working concentration of $3 \%$, BE was slightly higher in Batsikol $(5 \%)$ and Fytoverm $(0.8 \%)$. In swede, differences in Batsikol and Fitoverm BE (the latter was superior) proved to be more significant, like the superiority of the chemical reference of Arrivo $(0.2 \%)$. In the first 2 weeks post-treatment, similar results in terms of cruciferous flea beetles were demonstrated in rape, but after 3 weeks a significantly better effect was observed when applying Batsikol. BE of BTB varied against carrot psyllid reaching $82.1 \%$ at 2 weeks post-treatment. At this, Batsikol efficacy was significantly lower. In general, except for the first week after treatment, the efficacy of BTB against carrot psyllid proved to be comparable with the Arrivo (chemical reference) $(0.2 \%)$ and the better biochemical preparations. It should be noted that a Batsikol analogue, Batsiturin, has been approved in Belarus against carrot psyllid; this agent is produced based on $B$. thuringiensis var. darmstadiensis $\left(\mathrm{Bt} \mathrm{H}_{10}\right)$. A single application of two samples of BTB $(12 \mathrm{~kg} / \mathrm{ha})$ and Batsikol (20 1/ha) in 2011 against crucifer flea beetles in the Kraut Krayzer cabbage variety resulted in a significant reduction of pest population 1 week after reatment which was comparable to that of the reference Ffytoverm preparation (3.3 1/ha) (Fig. 1, A). However, the number of crucifer flea beetles began to increase later in all variants. With double treatments with Batsikol (total of $40 \mathrm{l} / \mathrm{ha}$ ) at an interval of 10 days (2014), the growth of pest numbers in the two studied varieties of cabbage (SAT-3 and Prestige) was prevented (see Fig. 1, B).

At farming conditions, both microbiological preparations (BTB, Lipidocide) and biochemical Fytoverm approved for cabbage can be used to control the leaf-eating lepidopteran pests. We have found that whitefly caterpillars, survived the treatment with biological preparations, were colonized with the entomophages Apanteles glomeratus L., and in late August they were eaten by predatory bugs (Ricromerus bidens L.).

In potato, BE of $5 \%$ Batsikol (20 1/ha, 2011) against Colorado potato beetle larvae of age I was $100 \%$ which was comparable to the reference of Arrivo $(0.4 \%, 1.6 \mathrm{l} / \mathrm{ha})$. Similar results were obtained in 2006 when potato was treated with BTB. 


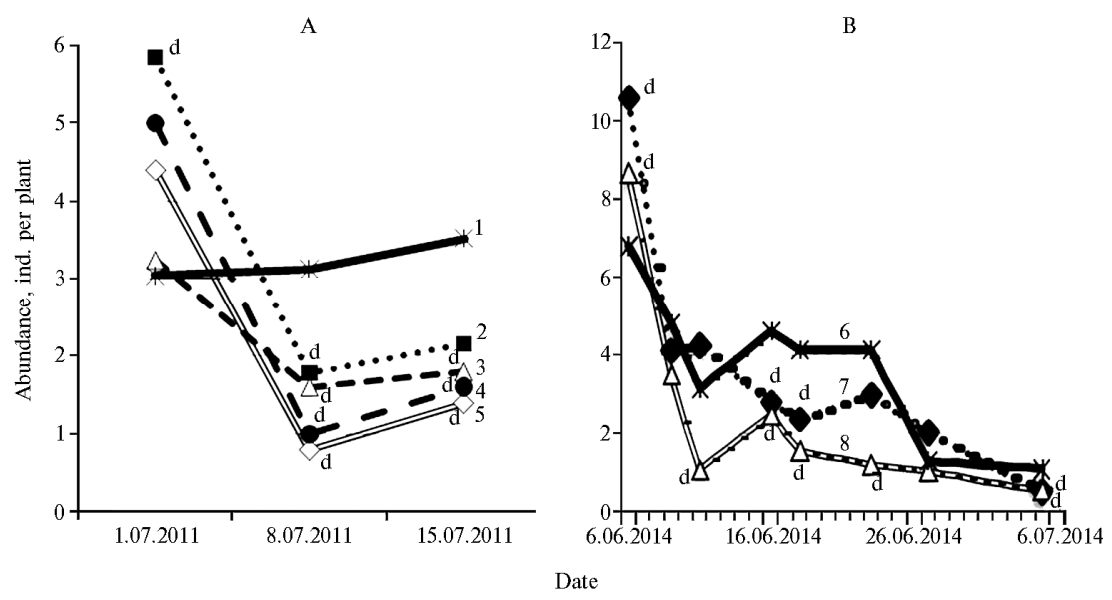

Fig. 1. Population dynamics (June to July) of cruciferous flea beetle (Phyllotreta undulata Kutschera) at a single treatment of cabbage variety of Kraut Krayzer with Fytoverm or microbiological preparations (A) and at double treatment of cabbage varieties of SB-3 and Prestige with Batsikol (B): 1 control (no treatment), 2 and 3 - Bitoxybacillin of various manufacturers, $4-$ Batsikol, $5-$ Fytoverm, 6 - control (no treatment, Prestige variety), 7 - Batsikol (SB-3 variety), 8 - Batsikol (Prestige variety). Doses and manufacturers are specified in the section «Technique»; letter $\mathrm{d}$ denotes the values significantly different from control at the date of registration $(\mathrm{p}<0.05$ according to Student $t$-test) (Educational and Experimental Garden of SPbSAU, Leningrad Province).

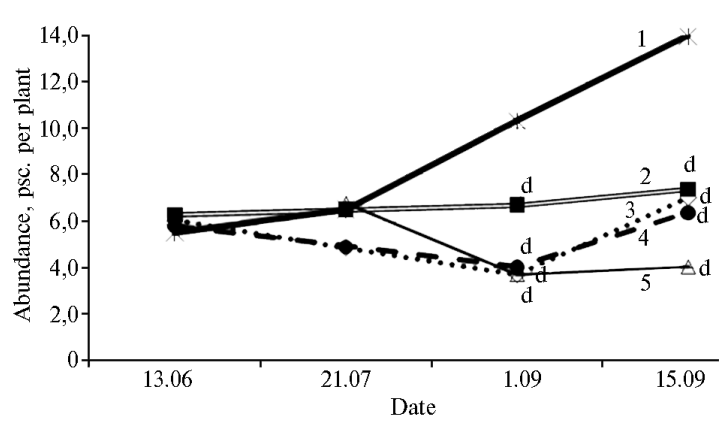

Fig. 2. Population dynamics (June to September) of wireworms at Nevskii potato variety treatment with Nemabakt and at various modes of the Metarhizium anisopliae experimental sample application: 1 - control (no treatment), 2 and $3-M$. anisopliae along bottom grooves and over the entire soil surface, 4 - treatment of tubers with $M$. anisopliae, 5 - Nemabakt. Doses and manufacturers are specified in the section «Technique»; letter d denotes the values significantly different from control at the date of registration ( $\mathrm{p}<0.05$ according to Student $t$-test) (Educational and Experimental Garden of SPbSAU, Leningrad Province, 2012). demonstrated. Such a method was more effective compared to the application of only biological products or embedding mustard into the soil (digging) [34].

In 2013, we continued the evaluation of various technologies for $\mathrm{Ne}$ mabakt application against wireworms (see Table 2), but significant differences were not found.

BTB and Batsikol were effective against raspberry mite in raspberry. BTB was comparable to Fytoverm in its BE against spider mite in the same crop (Table 3). The death of strawberry transparent and spider mites due to BTB has been proven in strawberry in the open ground. However, better results were obtained with a combination of spraying with biological products and predatory mite Amblyseius colonization (see Table. 3). 


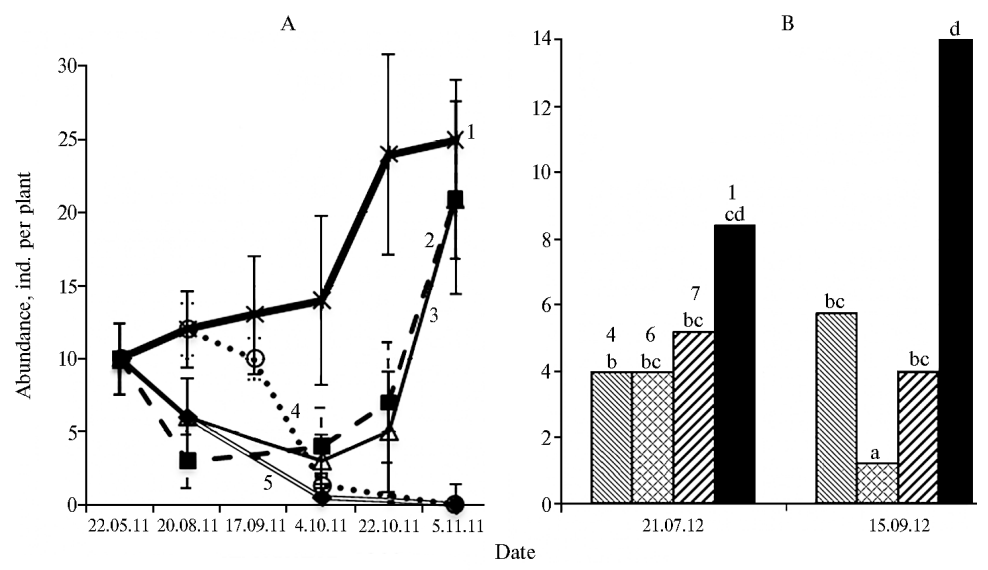

Fig. 3. Population dynamics (May to November) of wireworms in the Nevskii potato variety at treatment with Metarhizium anisopliae (A) and Nemabakt (B) in combination with embedding mustard Sinapis alba L. plants: 1 - control (no treatment), 2 - repellent Dachnik, 3 - Metarhizium anisopliae, 4 - mustard, 5 - mustard + Metarhizium anisopliae, $6-$ mustard + Nemabakt, 7 Nemabakt. Doses and manufacturers are specified in section «Technique». Confidence intervals of 0.95; similar letters mark the values not significantly different ( $\mathrm{p}>0.05$ according to Student $t$-test) (garden plot, Gatchina Region, Leningrad Province).

2. Efficacy of various treatment with Nematobakt against wireworms in the Nevskii potato variety (garden plot, Gatchina Region, Leningrad Province, 2013)

\begin{tabular}{|c|c|c|c|c|}
\hline Parameter & A & B & $A+B$ & Control (without treatment) \\
\hline $\begin{array}{l}\text { Number of wireworms prior to } \\
\text { planting } \pm \mathrm{SE} \text {, ind. } / \mathrm{m}^{2}\end{array}$ & $3.5 \pm 0.96^{\mathrm{b}}$ & $3.0 \pm 0.65^{b}$ & $3.5 \pm 0.63^{b}$ & $3.0 \pm 1.29^{\mathrm{ab}}$ \\
\hline $\begin{array}{l}\text { Number of wireworms at } \\
\text { harvesting } \pm \mathrm{SE} \text {, ind. } / \mathrm{m}^{2}\end{array}$ & $1.8 \pm 0.55^{\mathrm{ab}}$ & $1.3 \pm 0.36^{\mathrm{a}}$ & $1.1 \pm 0.32^{\mathrm{a}}$ & $4.3 \pm 1.58^{\mathrm{ab}}$ \\
\hline Biological efficacy, \% & 64.4 & 71.2 & 78.6 & 0 \\
\hline Damaged tubers \pm SE, \% & $5.0 \pm 1.54 \mathrm{c}$ & $8.0 \pm 1.57^{\mathrm{d}}$ & $4.8 \pm 1.06^{\mathrm{c}}$ & $16.0 \pm 3.67 \mathrm{e}$ \\
\hline Damaged tubers \pm SE, \% & $69 \pm 26.4$ & $50 \pm 15.1$ & $70 \pm 22.5$ & 0 \\
\hline
\end{tabular}

With high density of strawberry blossom weevil, Batsikol demonstrated a highly significant $(\mathrm{p}<0.001)$ efficacy. Its BE with a double treatment was not inferior to Actellic. With low initial density of this pest, BTB at a concentration of 2.5-3\% demonstrated not a bad efficacy 3 weeks after treatment. This variant was comparable to Fytoverm and Actellic, and slightly inferior to Spintor and Vertimek (see Table 3).

3. Biological efficacy (\%) of microbiological and chemical preparations against pest insects in berry crops depending on the post-treatment period (Leningrad Province, 2009-2013)

\begin{tabular}{|c|c|c|c|c|}
\hline \multirow{2}{*}{ Pest } & \multirow{2}{*}{$\begin{array}{l}\text { Preparation, } \\
\text { concentration }\end{array}$} & \multicolumn{3}{|c|}{ Period after treatment } \\
\hline & & 1 week & 2 weeks & 3 weeks \\
\hline B 1 a ck & $\mathrm{t}$ (educational and $\mathrm{e}$ & ental garden $\mathrm{o}$ & SPbSAU) & \\
\hline \multirow[t]{4}{*}{ Eriophyidae mites } & Bitoxybacillin, $2 \%$ & $99_{1}-54_{2}^{+}(2)$ & $16_{2}-30_{1}^{+}(2)$ & $0_{2}-17_{1}^{+}(2)$ \\
\hline & Fytoverm, $0.4 \%$ & $93{ }_{1}^{*}-100_{2} *(2)$ & $71_{2}^{*}-76_{1} *(2)$ & $60.8_{2}^{*}(1)$ \\
\hline & Spark, $0.1 \%$ & $100_{2} *(1)$ & $54.6_{2}^{*}(1)$ & $32.1_{2}(1)$ \\
\hline & d raspberry & Region) & & \\
\hline \multirow[t]{2}{*}{$\begin{array}{l}\text { Raspberry mite (Eriophyes } \\
\text { gracillis Nal.) }\end{array}$} & Bitoxybacillin $3 \%$ & $47.9 *(1)$ & $59.6 *(1)$ & $58.8^{*}(1)$ \\
\hline & Batsikol, & $96.3 *(1)$ & - & $89.8(1)$ \\
\hline \multirow{2}{*}{$\begin{array}{l}\text { Spider mite (Tetranychus } \\
\text { urticae Koch) }\end{array}$} & Bitoxybacillin, $3 \%$ & $54 *-68 *(2)$ & $94.6 *-95.1 *(2)$ & $81 *-89 *(2)$ \\
\hline & Fytoverm, $0.4 \%$ & $96.8^{*}(1)$ & $95.8 *(1)$ & $91.8^{*}(1)$ \\
\hline \multirow{2}{*}{$\begin{array}{l}\text { Strawberry mite (Tarsonemus } \\
\text { pallidus Banks) } \\
\text { Strawberry blossom weevil (Anthonomu }\end{array}$} & Bitoxybacillin, 2-2.5\% & $\begin{array}{c}25-46^{+}(2) \\
99.2^{++*}\end{array}$ & $70^{+}-86^{*}(2)$ & $63^{+*}-73(2)$ \\
\hline & Bitoxybacillin, $2.5-3 \%$ & $30_{4}-38_{5}(2)$ & $32.5_{4}(1)$ & $40_{4}^{*}-54_{5}^{*}(2)$ \\
\hline
\end{tabular}




\begin{tabular}{|c|c|c|c|}
\hline \multirow[b]{2}{*}{ Batsikol, $5 \%, 2$ times } & & \multicolumn{2}{|c|}{ Continued Table } \\
\hline & $63.73^{*}(1)$ & $29.23 *(1)$ & $22.23^{*}(1)$ \\
\hline & & $47.0_{3} *(1)$ & $39.73^{*}(1)$ \\
\hline Fytoverm, $0.4 \%$ & $40.34^{*}$ & $29.3_{4}$ & $43.5_{4}^{*}$ \\
\hline Actellic, $0.1 \%$ & $56_{5}^{*}-73_{3}^{*}(2)$ & $51.0_{3}^{*}(1)$ & $50{ }_{3}^{*}-51_{5}^{*}(2)$ \\
\hline Spintor, $0.4 \%$ & $58.2_{5}(1)$ & - & $73.05^{*}(1)$ \\
\hline Vertimec, $0.4 \%$ & $50.8_{5}^{*}(1)$ & - & $59.75^{*}(1)$ \\
\hline Sochva, $1 \%$ & $62.04 *(1)$ & $42.64 *(1)$ & $47.24 *(1)$ \\
\hline
\end{tabular}

$\mathrm{N}$ o t e. Asterisks denote statistically proven values (probability of differences from control of more than $99 \%$ ); in brackets: the number of independent replications; «+» - in combination with Amblyseius, «++» - in combination with Amblyseius in greenhouse, «+++» - estimation based on the damage to fruit elements. Similar indices mark the tests performed in comparative experiments at the same time under similar conditions. Intervals are given for timely (years) or spatially much separated replicates. The dashes mean that calculation has not been performed.

4. Efficacy of Batsikol and Fytoverm against strawberry blossom weevil (Anthonomus rubi Hbst.) in various strawberry varieties (Fragaria ananassa) (garden plot, St. Petersburg-Pushkin, 2013)

\begin{tabular}{|c|c|c|c|c|}
\hline \multirow{2}{*}{ Variety } & \multicolumn{2}{|c|}{ Average bud number per plant $\pm \mathrm{SE}$} & \multirow{2}{*}{$\begin{array}{l}\text { Undamaged } \\
\text { buds } \pm \text { SE, } \%\end{array}$} & \multirow{2}{*}{$\mathrm{BE}, \%$} \\
\hline & damaged & total & & \\
\hline \multicolumn{5}{|c|}{ Control (no treatment) } \\
\hline Polka & $9.7 \pm 0.50^{\mathrm{f}}$ & $27.7 \pm 0.92^{\mathrm{jk}}$ & $65.1 \pm 2.14^{\mathrm{d}}$ & \\
\hline Surprise for Olympics & $12.5 \pm 0.87 \mathrm{~g}$ & $41.1 \pm 2.24 \mathrm{~h}$ & $69.7 \pm 1.65^{\mathrm{cd}}$ & \\
\hline Tsarskoselskaya & $10.8 \pm 1.18^{\mathrm{fg}}$ & $40.6 \pm 1.46^{\mathrm{h}}$ & $73.2 \pm 1.59^{\mathrm{c}}$ & \\
\hline \multicolumn{5}{|c|}{ B a t s i k ol $(25$ l/ha $)$} \\
\hline Polka & $4.2 \pm 0.50^{\mathrm{e}}$ & $24.2 \pm 1.52^{\mathrm{k}}$ & $82.5 \pm 1.82^{\mathrm{b}}$ & 50.0 \\
\hline Surprise for Olympics & $4.4 \pm 0.47 \mathrm{e}$ & $33.1 \pm 1.23^{\mathrm{i}}$ & $86.6 \pm 1.40^{\mathrm{ab}}$ & 55.7 \\
\hline Tsarskoselskaya & $3.5 \pm 0.49^{\mathrm{e}}$ & $31.0 \pm 1.09^{\mathrm{i}}$ & $88.7 \pm 1.52^{\mathrm{a}}$ & 57.7 \\
\hline \multicolumn{5}{|c|}{ Fy t over m $(3.31 / \mathrm{ha})$} \\
\hline Polka & $4.6 \pm 0.80 \mathrm{e}$ & $24.4 \pm 2.00^{\mathrm{k}}$ & $80.9 \pm 2.13^{b}$ & 45.4 \\
\hline Surprise for Olympics & $3.8 \pm 0.50^{\mathrm{e}}$ & $32.1 \pm 2.10^{\mathrm{ij}}$ & $88.3 \pm 1.38^{\mathrm{a}}$ & 61.3 \\
\hline Tsarskoselskaya & $3.8 \pm 0.38^{\mathrm{e}}$ & $31.4 \pm 1.57^{\mathrm{i}}$ & $88.0 \pm 1.37 \mathrm{a}$ & 55.0 \\
\hline
\end{tabular}

Low efficacy of BTB against strawberry blossom weevil in the initial period after treatment in case the organic method of strawberry growing was used may be probably compensated by the additional application of the Sochva repellent (produced by pyrolysis of wood), and preparation Dachnik (produced of fir conifer) that have shown good results in this pest control in the strawberry in Taitsy farm [35].

Protection of strawberry from strawberry blossom weevil proved to be effective with triple treatments with Batsikol (Table 4).

Our experiments performed in the private garden demonstrated about the same biological efficiency (55-60\%) of Fytoverm and Batsikol, although in the Polka variety it was somewhat lower (45-50\%). Protection measures performed during budding made it possible to preserve significantly the crop in the Polka variety, a weakly stable and, therefore, more damaged by weevil.

Thus, our studies have shown the possibility of effective use of microbiological plant protection against the main pest insects and mites in vegetables, berries and potatoes under the conditions of Leningrad Province. By selecting different techniques, methods, timing, number of treatments, the efficacy of biological preparations comparable to chemical treatments can be achieved. A possibility of combined use of differently targeted biological preparations (biofungicides and bio-insecticides) in tank mixtures was found in garden strawberries. Biological preparations in combination with some repellents and agro technical measures can provide reliable protection of vegetable and fruit crops, and potatoes from pest species. In strawberry, additional monitoring is required to specify the timing and intervals between treatments. In most experiments carried out in recent years, the cost biological preparations was recouped better than in the beginning of the first decade this century. This is due to a rapid increase in prices of agricultural products compared to the cost of biological 
preparations. Some tested microbiological preparations, primarily Batsikol, should be included in the plan of state registration trials for cabbage, potatoes, and garden strawberries.

\section{R E F E R E N C E S}

1. Yul R.J., Cho i J.Y., Li M.S., J i n B.R., J e Y.H. Bacillus thuringiensis: as a specific, safe, and effective tool for insect pest control. J. Microbiol. Biotechnol., 2007, 17(4): 547-559.

2. Sanahuja G., B anakar R.,Twyman R.M., Capel T., Christou P. Bacillus thuringiensis: a century of research, development and commercial applications. Plant Biotechnol. J., 2001, 9: 283-300 (doi: 10.1111/j.1467-7652.2011.00595.x).

3. Mohammed S.H., Saedy M.A., Enan M.R., Nasser E.I., G a reeb A.,S 1 ah A.M. Biocontrol efficiency of Bacillus thuringiensis toxins against root-knot nematode, Meloidogyne incognita. J. Cell Mol. Biol., 2008, 7(1): 57-66.

4. Promdonkoy B., Chewawiwat N., Tanapongpinat S., Luxananil P., $\mathrm{P}$ a n y i m S. Cloning and characterization of a cytolytic and mosguitolarvicidal delta-endotoxin from Bacillus thuringiensis subsp. darmstadiensis. Cur. Microbiol., 2003, 40: 94-98.

5. Douville M., Gagné F., B la is e C., André C. Occurrence and persistence of Bacillus thuringiensis (Bt) and transgenetic Bt corn cry $1 \mathrm{Ab}$ gene from an aquatic environment. Ecotoxicology and Environmental Safety, 2007, 66: 195-203 (doi: 10.1016/j.ecoenv.2006.01.002).

6. Reddy C.V.P., Tangtrakulwanich K., Wu S., Miller J., Ophus V.L., Prewe t t J., Jaronski S.T. Evaluation of the effectiveness of entomopathogens for the management of wireworms (Coleoptera: Elateridae) on spring wheat. J. Invert. Pathol., 2014, 120: 4349 (doi: 10.1016/j.jip.2014.05.005).

7. He rk W.G., Ve rn o n R.S. Mortality of Metarhizium anisopliae - infected wireworms (Coleoptera: Elateridae) and feeding on wheat seedlings are affected by wireworm weight. J. Entomol. Soc. Brit. Columbia, 2011, 108: 38-40.

8. S u g i a n M. Biology, monitoring and management of economically important wireworm species (Coleoptera: Elateridae) in organic farming. Inaugural-Dissertation zur Erlangung des Grades Doktor der Agrarwissenschaften vorgelegt am 23. Zu Bonn, November 2012.

9. Ericsson J.D., Kabaluk J.T., G oe t te 1 M.S., Myers J.H. Spinosad interacts synergistically with the insect pathogen Metarhisium anisopliae against the exotic wireworms Agriotes lineatus and Agriotes obscurus (Coleoptera: Elateridae). J. Econ. Entomol., 2007, 100(1): 31-38 (doi: 10.1603/0022-0493(2007)100[31:SISWTI]2.0.CO;2).

10. Kaya H.K., Aguillera M.M., Alumai A., Choo H.Y., Torre M., Fodor A., Ganguly S., Hazir S., Lakatos T., Pye A., Wilson M., Yamanaka S., Yang H., Ehle rs R.-U. Status of entomopathogenic nematodes and their symbiotic bacteria from selected countries or region of the world. Biol. Control, 2006, 38: 134-155 (doi: 10.1016/j.biocontrol.2005.11.004).

11. P a v lov a E.A., M a s lov a I.V. Sel'skokhozyaistvennye vesti, 2014, 1: 14-15.

12. Obzor fitosanitarnogo sostoyaniya posevov sel'skokhozyaistvennykh kul'tur v Rossiiskoi Federatsii v 2014 godu i prognoz poyavleniya vrednykh ob"ektov v 2015 godu [An overview on phytosanitary status of crops in the Russian Federation in 2014 with predicting emergency of harmful agents in 2015]. Moscow, 2014.

13. Smirnov O.V. Patotipy Bacillus thuringiensis i ekologicheskoe obosnovanie ikh ispol'zovaniya $v$ zashchite rastenii. Avtoreferat doktorskoi dissertatsii [Bacillus thuringiensis pathotypes and ecological bases for their use in plant protection. DSc Thesis]. St. Petersburg-Pushkin, 2000.

14. D a n i lo v L.G. Biologicheskie osnovy primeneniya entomopatogennykh nematod (Rhabditida: Steinernematidae. Heterorhabditidae) v zashchite rastenii. Avtoreferat doktorskoi dissertatsii [Biological background for use of entomopathogenic nematodes (Rhabditida. Steinernematidae. Heterorhabditidae) in plant protection. DSc Thesis]. St. Petersburg, 2001.

15. Kandybin N.V., Patyka T.I., Ermolova V.P., Patyka V.F. Mikrobiokontrol' chislennosti nasekomykh $\mathrm{i}$ ego dominanta Bacillus thuringiensis [Microbiocontrol of insects, and Bacillus thuringiensis as a predominate agent]. St. Petersburg-Pushkin, 2009.

16. Dobrokhotov S.A., Paz yna L.F. V sbornike: Biologicheskii metod $v$ sel'skom khozyaistve Leningradskoi oblasti v 2002 godu [In: Biomethod in agriculture of Leningrad Province in 2002]. St. Petersburg, 2002: 19-22.

17. Dobrokhotov S.A., Glush che nko A.B., Shapoval P.V. Zashchita i karantin rastenii, 2006, 10: 25-26.

18. Dob rok hot ov S.A. Sel'skokhozyaistvennye vesti, 2008, 1: 18-19.

19. Dobrokhotov S.A., S mirnov O.V., Grishechkina S.D., Karaev D.O. Materialy 3-i Vserossiiskoi nauchnoi konferentsii s mezhdunarodnym uchastiem «Ekologicheskie problemy severnykh regionov i puti ikh resheniya». Chast' 2. [Proc. $3^{\mathrm{d}}$ Conf. «Environmental problems in the north territories of Russia and approach to their solution». Part 2]. Appatity, 2010: 11-17.

20. Vo j i novi c M.Z. Biological control of oldseed rape pests with entoimopathogenic nematodes. Doctoral Thesis in Agricultural Zoology. Helsinki, 2010. 
21. Andrews N., Ambrosino M., F is her G., Ro ndo n S.I. Wireworm. In: Biology and manegement in potatoes in the Pacific Northwest. Oregon, 2008.

22. Wibe A., Cross J., Borg-Karlsson A.K., Hall D.R., Trandem N., Sigs ga a rd L., B a roffio C., R alle B., Fountain M.T. Management of strawberry blossom weevil and European tarnished plants bug in organic strawberry and raspberry using semiochemical traps — «Softpest Multitrap». NJF report, 2013, 9(8): 31-32.

23. Svens son B., Hakans on T., Kronhed A., Manduric S., Winter C., Janss o $n$ J. IPM in strawberries, part 1: IPM as a collaboration between farmers, advisor and researchers. NJF report, 2013, 9(8): 26.

24. Sigsga ard L., Eilenberg J., Enkega ard A., Esbjerd P., Hansen E.W., $\mathrm{B}$ rodsga ard H., P e te rs e $\mathrm{n}$ B.D. Integrating biological control measures against strawberry pets. NJF report, 2009, 5(9): 12.

25. O u re d n i c k ova J. Efficacy of some selected products against the strawberry blossom weevil (Anthonomus rubi Herbst., 1795). Vedecke prace ovocnarske, 2011, 22: 213-222.

26. A a s e n S.S., Trand e n N. Strawberry blossom weevil Anthonomus rubi Herbst (Col.: Curculionidae): relationships between bug damage, weevil density, insecticide use, and yield. $J$. Pest. Sci., 2006, 79: 169-174 (doi: 10.1007/s10340-006-0131-z).

27. B e rlung R. Organic production of strawberries. Focus on practical applications. Doctoral thesis. Alnarp, 2007.

28. Dobrokhotov S.A., Smirnov O.V., Laptev G.Yu., Grishechkina S.D., D a ni lov L.G., A n is i m ov A.I. Sel'skokhozyaistvennye vesti, 2008, 4: 24-25.

29. Dobrokhotov S.A., Anisimov A.I., S mirnov O.V. Sel'skokhozyaistvennye vesti, 2009, 1: 38.

30. D o b r o k h o t o v S.A. Biologicheskaya zashchita chernoi smorodiny i zemlyaniki ot vreditelei. $V$ sb. nauch. tr. SPbGAU: Nauchnoe obespechenie razvitiya APK v usloviyakh reformirovaniya [In: Research base for agro industry development in Russia under reforming]. St. Petersburg, 2009: 86-88.

31. Dobrokhotov S.A., A n is i m ov A.I., K a ra ev D.O. Materialy mezhdunarodnoi nauchno-prakticheskoi konferentsii «Integrirovannaya sistema zashchity rastenii: strategiya i taktika» [In: Research base for agro industry development in Russia under reforming]. St. Petersburg. Minsk, 2011: 19-23.

32. Parrika P., Tuovinen T., Lindkvist I., Ruuttunen P. Zashchita rastenii $v$ Finlyandii. Yagody i frukty (Spravochnik) [Plant protection in Finland. Berry and fruit crops: handbook]. Mikkeli, Finlyandiya, 2012

33. Barsics F., Haubruge E., Verheggen F.J. Wireworms management: An overview of the existing methods, with particular regards to Agriotes spp. (Coleoptera: Elateridae). Open Access. Insects, 2013, 4: 117-152 (doi: 10.3390/insects4010117)

34. Dobrokhotov S.A., An is i mov A.I., Danilov L.G., Led nev G.R. Vestnik zashchity rastenii, 2014, 3: 25-33.

35. Dobrokhotov S.A., Anisimov A.I., Lavrova I.S. V sbornike nauchnykh trudov SPbGAU: Nauchnoe obespechenie razvitiya $A P K V$ usloviyakh reformirovaniya [In: Research base for agro industry development in Russia under reforming]. St. Petersburg, 2012: 99-102. 